Journal of Al-Azhar University Engineering Sector

Vol.16, No, 61, October 2021, $1135-1155$

\title{
HYPERTHERMIA FOR BREAST CANCER TREATMENT USING A SLOTTED MICROSTRIP PATCH ANTENNA ARRAY
}

\author{
Rana M. Shehata ${ }^{1}$, Mohamed I. Badawi ${ }^{2}$, Nour Eldin Ismail ${ }^{3}$ \\ ${ }^{1}$ Electrical Engineering Department, Alexandria Institute of Engineering and Technology (AIET), \\ Alexandria, Egypt. \\ ${ }^{2}$ Department of Medical Equipment Technology, Faculty of Applied Health Sciences Technology, \\ Pharos University, Alexandria, EGYPT. \\ ${ }^{3}$ Electrical Department, Faculty of Engineering, Alexandria University, Alexandria, EGYPT. \\ *Corresponding Author E-mail: Rana.Mahmoud@aiet.edu.eg
}

\begin{abstract}
The main objective of this paper is to investigate the potential of using an inset-fed rectangular slot microstrip patch antenna (MSA) array applicator operating at $2.45 \mathrm{GHz}$ for hyperthermia treatment. Microwave hyperthermia is considered as an effective method for the treatment of breast cancer. The challenge in hyperthermia is to damage and kill the cancerous tissue by raising its temperature above $42^{\circ} \mathrm{C}$ without exposing healthy tissue to excessive temperature elevations. The thermal energy is coupled onto the breast tissue through eight MSAs array applicator that transmits microwave energy. The 3D numerical model consists of an eight MSA array elements irradiating breast tissue with tumor is constructed using Computer Simulation Technology (CST) Studio 2019 software. The results obtained shows that the proposed system is capable of steering the array beam to tumor locations by changing the phase and the feeding current distribution of antenna array elements to achieve a precise hyperthermia to the cancerous tissues and minimal injury to normal tissues

KEYWORDS: Hyperthermia; Microstrip Patch Antenna; Microwave Frequency; Breast Cancer; Slotted Patch; Beam Steering; CST studio software

$$
\begin{aligned}
& \text { علاج سرطان الثذي بالفرط الحراري عن طريق مصفوفة هوائي ميكروشريطية ذو فتحات } \\
& \text { رنا محمود شحاتة1، محمد إسماعيل بدوي² ، نور الدين إسماعيل3 }
\end{aligned}
$$

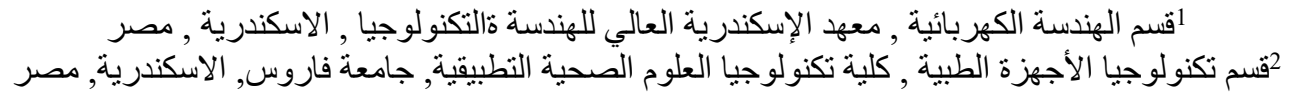

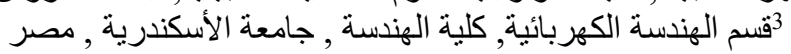

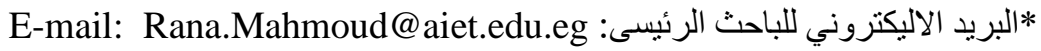


تهدف هذه الرساله إلى التحقق من إمكانية استخدام مجموعة من عناصر الهو ائيات الميكروشريطية (MSA) مستطيلة الشكل ذات فتحات

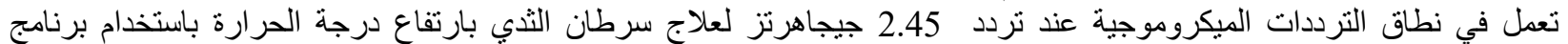

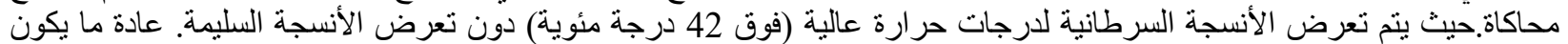

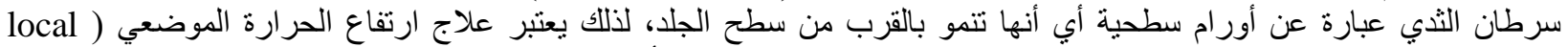
(hyperthermia treatment

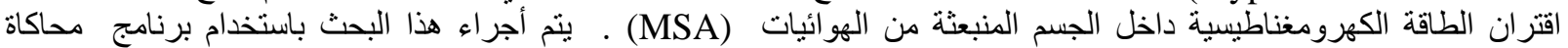
Computer Simulation Technology (CST) Studio 2019 software

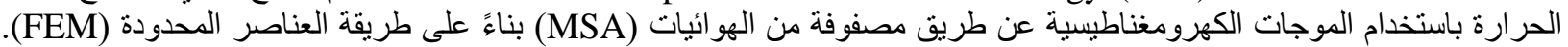

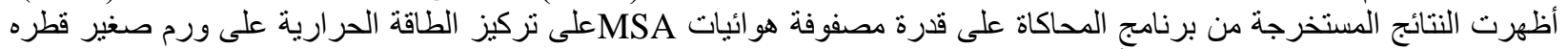



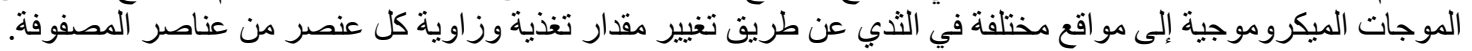

الكلمات المفتاحية: الفرط الحراري, هو ائي ميكروشريطي, ترددات ميكروموجية, سرطان الثئي, هو ائي ذو فتحات, توجيه حزمة الإشعاع, برنامج تكنولوجيا المحاكاة الحاسوبية المبرية

\section{INTRODUCTION}

Breast cancer is one the greatest common types of cancer which threatening health in middle-aged women around worldwide. In 2020, statistical study conducted by American Cancer Society revealed that breast cancer yielded 42,170 women death and estimated that more than 270,000 new cases of invasive breast cancer will be diagnosed among women in the United States (Society, 2020). Breast cancer early diagnosis is the key to thrashing the breast cancer. While X-ray mammography (MMG) remains the typical for tumor screening, its essential limitations are also documented such as uncomfortable or painful breast compression and exposure to harmful ionizing radiation (Tayel et al., 2016).

The disadvantages and limitations of the current clinical detection techniques motivated researchers to investigate and develop new imaging techniques based on microwaves because it has several advantages compared with current techniques as discussed in (Chaudhary et al., 1984; Nikolova, 2011). There are available techniques for treating breast cancer often introduce strong side effects and known as invasive technique. The most common invasive treatment is surgical treatment such as mastectomy. Nowadays microwave (MW) hyperthermia is a noninvasive technique treatment for breast cancer with minimum side effects. In hyperthermia treatment, cancer tissue is exposed to high temperatures (above $42^{\circ} \mathrm{C}$ ) produced from electromagnetic (EM) energy, while maintaining a normal temperature in other areas to avoid any damage (Korkmaz et al., 2015; Leggio et al., 2015). The EM radiation is emitted from a number of antennas surrounding the body part affected by tumor.

All biomedical systems require antennas to be embedded in a movable applicator system, hence the antenna must be light, small and portable which are non-bulky. Therefore this development has focused technologically much effort into the design of microstrip patch antennas (Balanis, 2016; G. Kumar \& Ray, 2002). The objective of this paper is to propose a noninvasive MW hyperthermia system that utilizes a MSA array applicator which is normally distributed around the breast model. The MSA is designed to operate at $2.45 \mathrm{GHz}$ with Industrial Scientific and Medical band (ISM: 2.4-2.4835 GHz) (McNeil, n.d.). The non-ionizing MW signals transmitted by the array elements will be constructively combined at the desired location and destructively added elsewhere which leads to an elevation the temperature above $42^{\circ} \mathrm{C}$ at the tumor location for a sufficient period of time. The temperature distribution inside the tissue is determined according to the rate of specific absorbed (SAR) by a breast tissue. The antenna parameters were optimized to enhance antenna performance and modified by etching circular slots on the radiating patch. The optimum slot radius, number of slots and separation distance between them were be examined by parameter sweep tool in CST that keep minimum return loss $\left(S_{11}\right)$ at the desired frequency $2.45 \mathrm{GHz}$. A comparison between the proposed antenna with and without slots has been studied for the maximum 
electric field and SAR distribution values at the tumor. Moreover, this paper introduces the effect of changing the feeding current and phase distribution of each patch antenna on steering the heating to specific area of the breast. A Finite Element Method (FEM) based on CST which is explained by (Kara, 1996) is used to simulate the electromagnetic (EM) field and temperature distribution inside the model. The single MSA with circular slots was fabricated for experimental verification. The measured results were agreement with the simulated results. Section 2 discusses the antenna structure with its modification and the proposed breast model. Section 3 contains simulation results and section 4 is devoted to the main conclusions.

\section{MATERIAL AND METHOD}

\subsection{Microstrip Patch Antenna (MSA) Structure}

The dimensions of patch antenna were calculated based on the three essential elements. These elements are the operation frequency $f r$, the height of substrate $h$ and the dielectric constant of substrate $\varepsilon_{\mathrm{r}}$. The frequency of patch antenna was designed to operate at $2.45 \mathrm{GHz}$. To miniaturize the size of patch antenna, the high permittivity dielectric material should be chosen. Hence, The FR4 was selected as a substrate material with $\varepsilon_{\mathrm{r}}=4.3$ and loss tangent $\delta=0.025$. For medical application purposes the applicator shouldn't be massive therefore, the substrate should be relatively thin less than $\left(0.02 K_{\text {air }}\right)$ (Waterhouse, 2003). Hence the substrate height selected is $1.6 \mathrm{~mm}$. The antenna is fed using an inset feed microstrip transmission line with $50 \Omega$ characteristic impedance. The width $W_{f}$ and length $L_{f}$ of the microstrip feed line is fixed at $3.137 \mathrm{~mm}$, and $12.77 \mathrm{~mm}$ respectively with inset depth from radiating patch $f i=8.85 \mathrm{~mm}$ to match with a characteristic impedance $\mathrm{Z}_{0}=50 \Omega$ (Bengal, 2014; Matin \& I.Sayeed, 2010; Ndujiuba et al., 2017). The formula of gab width $g$ that provides best impedance matching can be obtained by (Matin \& I.Sayeed, 2010). The radiating patch is a rectangular shape with width $W p$ and length $L p$. On the other side of the substrate, a ground plane with width $W g$ and length $L g$ is placed with a thickness of $t g=0.035 \mathrm{~mm}$. A perfect electric conductor (PEC) material was chosen for patch and ground plane. The antenna parameters of patch antenna are analyzed by applying the transmission line method explained by (Bernard et al., 2013).The design procedure to calculate the physical antenna parameters is based on the literature quoted (Balanis, 2016; Paul et al., 2015). The proposed MSA parameters are listed in Table 1. The final layout of the inset fed MSA is shown in Fig. 1.

Table 1: MSA design parameters

\begin{tabular}{|c|c|c|}
\hline Parameter & Description & Dimension $(\mathbf{m m})$ \\
\hline $\mathrm{Wp}$ & Patch width & 37.60 \\
\hline$L p$ & Patch length & 29.15 \\
\hline$W g$ & Ground and substrate width & 47.20 \\
\hline$L g$ & Ground and substrate length & 38.75 \\
\hline$h$ & Substrate height & 1.6 \\
\hline$t g$ & Patch and ground thickness & 0.035 \\
\hline$f i$ & Inset fed depth & 8.85 \\
\hline$w f$ & Feed line width & 3.137 \\
\hline$l f$ & Feed line length & 12.77 \\
\hline$g b$ & Gab between patch and inset fed & 1 \\
\hline
\end{tabular}




\subsection{Patch Antenna Performance}

The return loss $\left(S_{11}\right)$ curve of the conventional inset fed rectangular MSA is shown in Fig. 2. However, the $S_{11}$ is not minimum at resonant frequency $2.45 \mathrm{GHz}$ ranging within ISM band (2.4 $\mathrm{GHz}-2.4835 \mathrm{GHz}$ ), but it records $-19.577 \mathrm{~dB}$ at $2.382 \mathrm{GHz}$ ranging from $2.3519 \mathrm{GHz}$ to 2.4129 GHz. According to (Patel, 2015) the antenna dimensions (Wp, Lp, Lg and Wg) are effected on variation of resonance frequency. Therefore, they have been optimized using the Trust Region Framework (TRF) algorithm available in CST optimizer in order to shift the minimum $\mathrm{S}_{11}$ at 2.45 GHz. The optimized values obtained are $\mathrm{Lp}=28.33 \mathrm{~mm}, \mathrm{Wp}=36.53 \mathrm{~mm}, \mathrm{Wg}=46.13 \mathrm{~mm}$ and $\mathrm{Lg}=37.93 \mathrm{~mm}$. As a result, the resonance frequency is shifted from $2.382 \mathrm{GHz}$ to $2.45 \mathrm{GHz}$ with minimum return loss $-17.994 \mathrm{~dB}$ ranging from $2.4186 \mathrm{GHz}$ to $2.4812 \mathrm{GHz}$ as shown in Fig. 3. Afterward, the inset depth $f i$ has been optimized from $8.85 \mathrm{~mm}$ to $7.965 \mathrm{~mm}$ in order to enhancement of the antenna performance for the entire frequency. Fig. 4 and Fig. 5 show the return loss and characteristic impedance respectively after optimizes $f i$. It could be seen that by varying $f i$ the impedance matching improved from 63 to $54.7 \mathrm{ohm}$. Also, $\mathrm{S}_{11}$ increased by 7.379 $\mathrm{dB}$ from $-17.994 \mathrm{~dB}$ to $-25.373 \mathrm{~dB}$ ranging from 2.4846 to $2.4148 \mathrm{GHz}$ with increased bandwidth from $62.6 \mathrm{MHz}$ to $69.8 \mathrm{MHz}$. Table 2 summaries the performance comparison among the conventional and optimized MSA antenna.



(a)

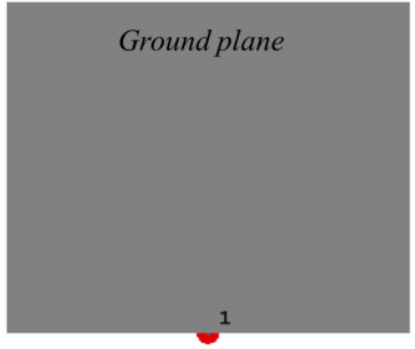

(b)

Figure 1: Final layout of the MSA (a) Front view (b) Side view 


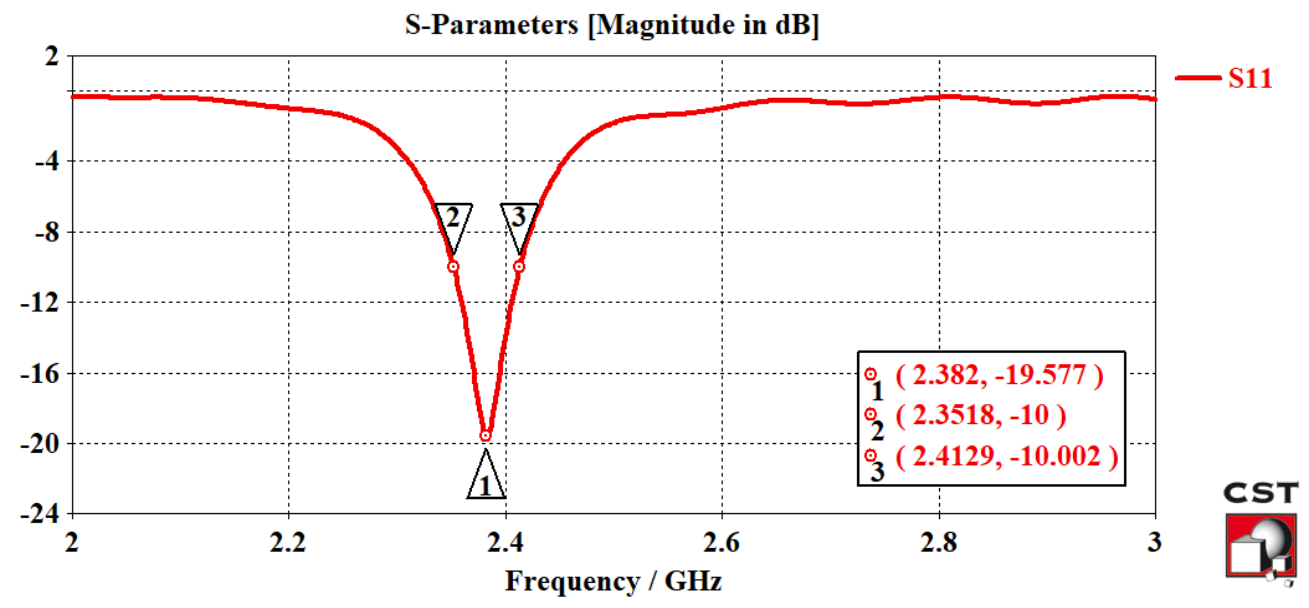

Figure 2: Return loss (S11) of the conventional MSA

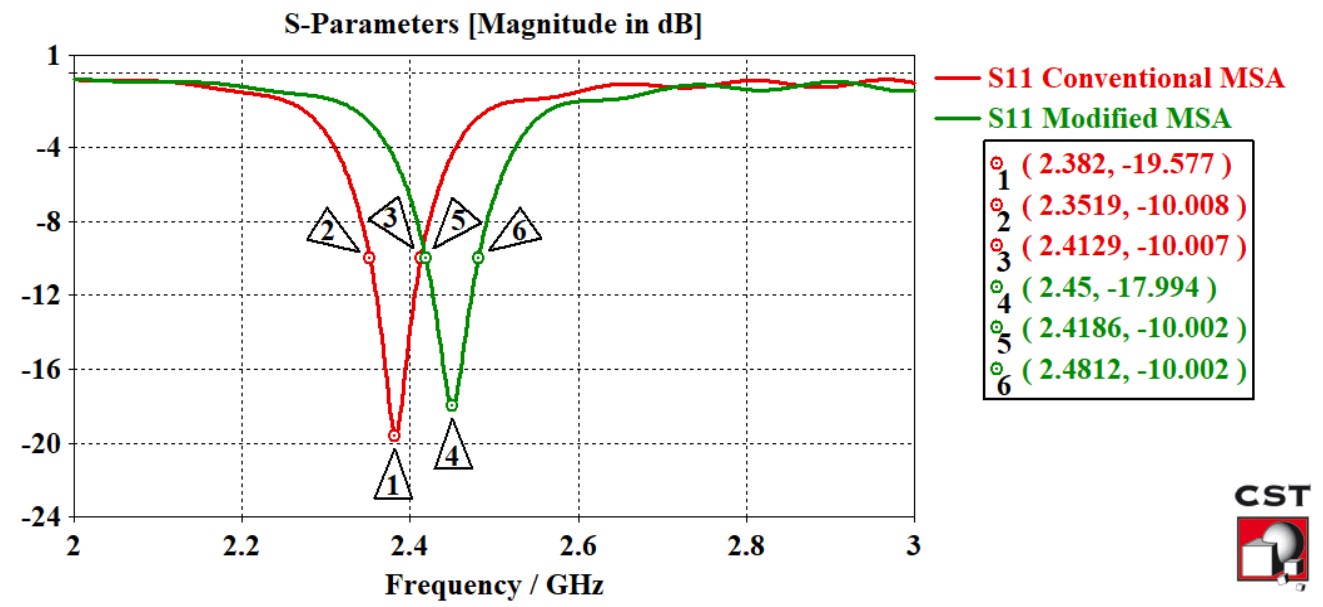

Figure 3: Return loss (S11) of the conventional and modified MSA 




Figure 4: Return loss $\left(S_{11}\right)$ before and after modify $f i$

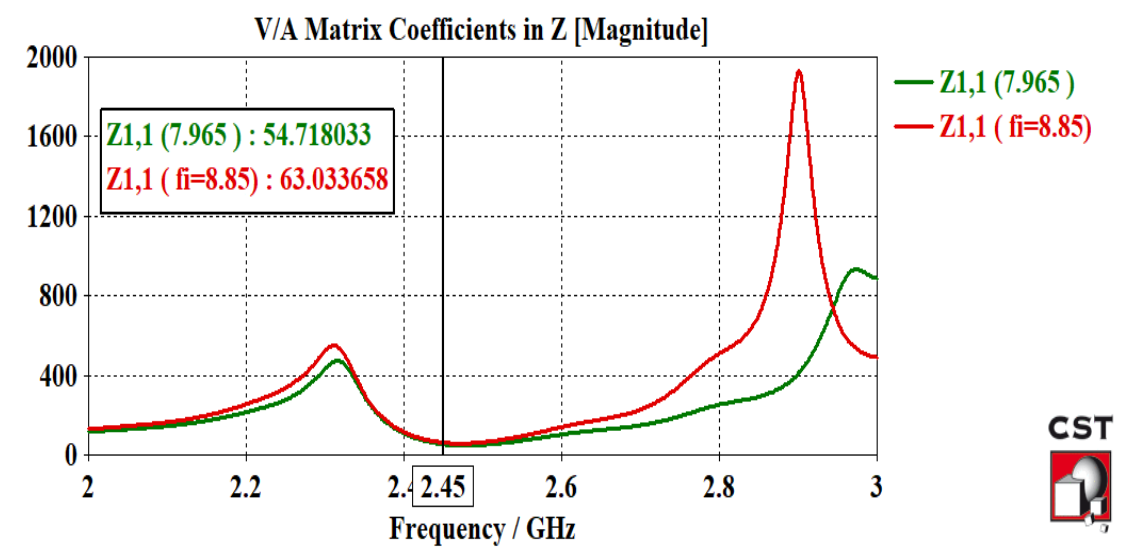

Figure 5: Characteristic impedance $\mathrm{Z}_{11}$ befor and after modify $f i$

Table 2: Performance comparison among the conventional and optimized antenna

\begin{tabular}{ccc}
\hline Antenna performance & $\begin{array}{c}\text { Conventional } \\
\text { antenna }\end{array}$ & Optimized antenna \\
\hline Resonance frequency $f r(\mathrm{GHz})$ & 2.382 & 2.45 \\
Return loss $\mathrm{S}_{11}(\mathrm{~dB})$ & -19.577 & -25.373 \\
Bandwidth $(\mathrm{MHz})$ & 61 & 69.8 \\
Characteristic impedance $\mathrm{Z}_{11}(\mathrm{ohm})$ & 63 & 54.71 \\
\hline
\end{tabular}




\subsection{Modification of (MSA) With Introducing Circular Slots}

For medical application propose the applicator should not be massive, therefore, the proposed MSA was modified by etching a circular slots on the radiating patch. A slot is made by making a circular hole on the radiating patch of the antenna. The current path on the patch can be increased with adding slots as compared to the without slot patch antenna because the current will need to flow around the hole, with a higher current density. However the slots are affected on the resonance frequency and make it move toward the lower frequency as mentioned in (R. Kumar et al., 2009; Paul et al., 2019). The novelty in this paper is how adding the circular slots to improve the efficiency of antenna with keeping the minimum return loss at the desired frequency $2.45 \mathrm{GHz}$. Several trails to decide the optimum number of slots, slot locations, slot radii and the separation distances between slots are processed that kept minimum $S_{11}$ at $2.45 \mathrm{GHz}$.

\subsubsection{The Optimum Slot Location}

The best location of the slots in the patch is at the area of low level of the current magnitude. Fig. 6 shows the current distribution along the patch. It is observed that the most current is distributed at the center of radiating patch but it has minimum values at the top and bottom of patch antenna. Thus, the best location for a slot is at the top and bottom of the patch.

\subsubsection{The Optimum Slot Radius}

The single circular hole will be located at top left side of the patch, with initially separation distance from the patch edge $(X=2, Y=2)$ along $X$ and $Y$ axis as shown in Fig 7. To decide the best slot radius, the slot radius is varied through parameter sweep tool in CST from $0.5 \mathrm{~mm}$ to $2 \mathrm{~mm}$ and the resonance frequency is determined in each case. Fig 8 shows the $S_{11}$ versus frequency for different values of slot radii. It is observed that the optimum value for slot radius that keep minimum $S_{11}$ at $2.45 \mathrm{GHz}$ is $\mathrm{r}=0.5 \mathrm{~mm}$.

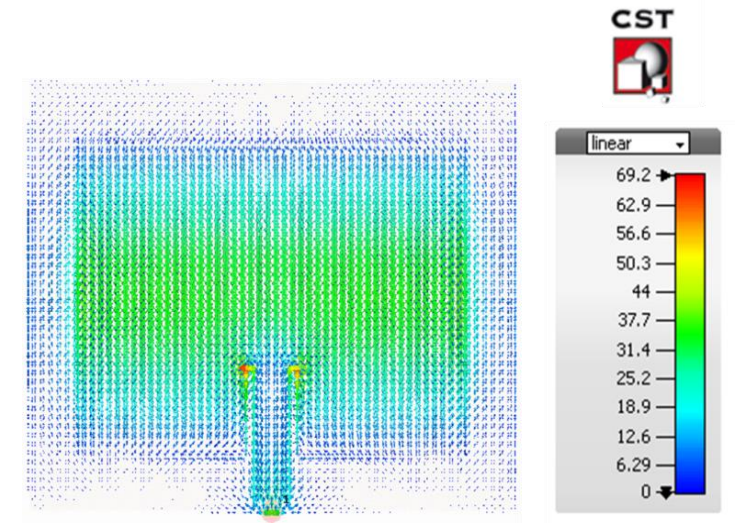

Figure 6: Current distribution of optimized MSA at $2.45 \mathrm{GHz}$

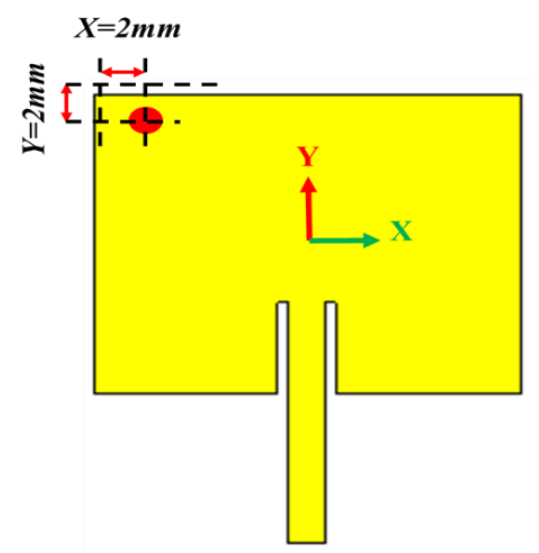

Figure 7: Single circular slots at the left top of patch with different radius 


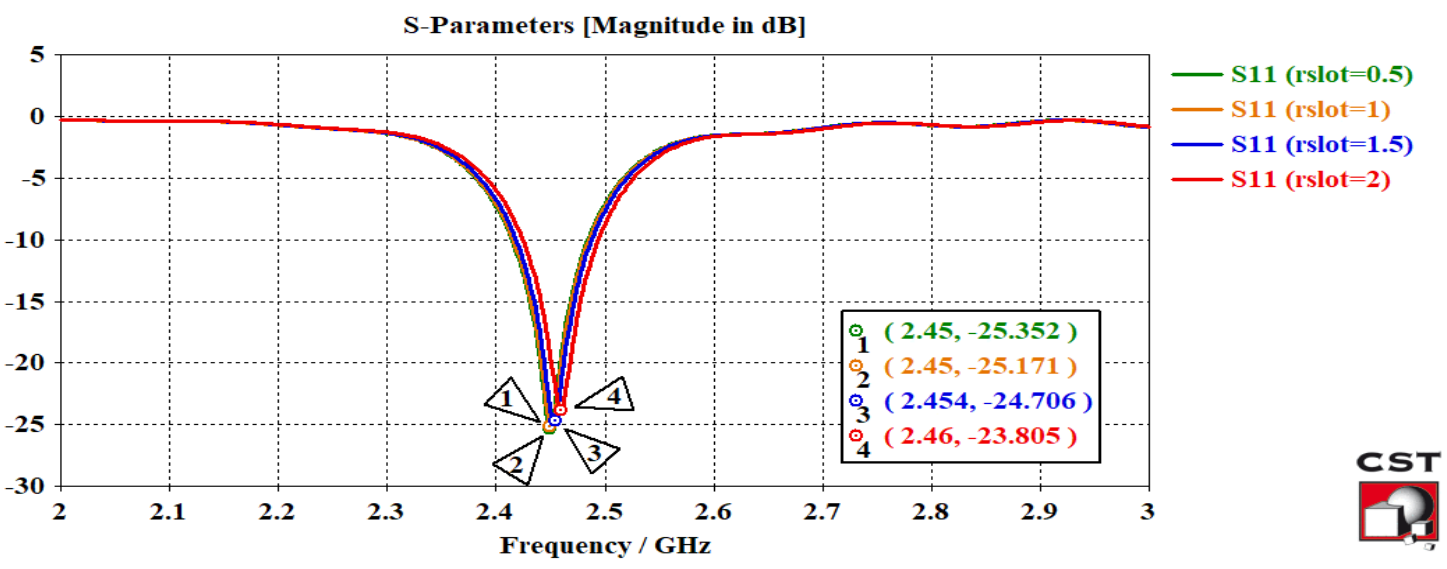

Figure 8: $\mathrm{S}_{11}$-Parameter for different slot radii from 0.5 to $2 \mathrm{~mm}$

\subsubsection{The Optimum Separation Distance Between The Slots}

In this section the best orientation of slots with the best separation distance between them is determined. Firstly, two circular holes are aligned horizontally onto X-axis and separated with different separation distance from $2 \mathrm{~mm}$ to $10 \mathrm{~mm}$ with step width equal 2 and fixed at $Y=2 \mathrm{~mm}$ as shown in Fig. 9-a. It is observed from Fig.10 that the resonance frequency $f r$ is not affected at any separation distance along Xaxis. So, the best separation along $X$-axis that gives minimum $S_{11}$ at $2.45 \mathrm{GHz}$ at $X=4 \mathrm{~mm}$. Then two circular slots are aligned vertically onto $\mathrm{Y}$-axis with different separation distance from $2 \mathrm{~mm}$ to $10 \mathrm{~mm}$ with step width equal 2 and fixed at $X=4 \mathrm{~mm}$ as shown in Fig. 9-b. From Fig. 11 it observed that if the circular slots are aligned onto $\mathrm{Y}$ - axis and the separation is increased than $2 \mathrm{~mm}$, the resonance frequency is affected slightly and $S_{11}$ will be increased. Therefore, the best separation distance along $\mathrm{Y}$-axis at $\mathrm{Y}=2$ $\mathrm{mm}$. Finally, it can be observed that if the slots are placed horizontally along $\mathrm{X}$-axis, the $f r$ and $S_{11}$ will not be affected. But if the slots are placed vertically along $\mathrm{Y}$-axis, the $f r$ and $\mathrm{S}_{11}$ will be affected because the slots began entrance into the high current region. Table 3 summarizes the corresponding relations between the separation distance between slots and its effect on MSA

S-parameters.

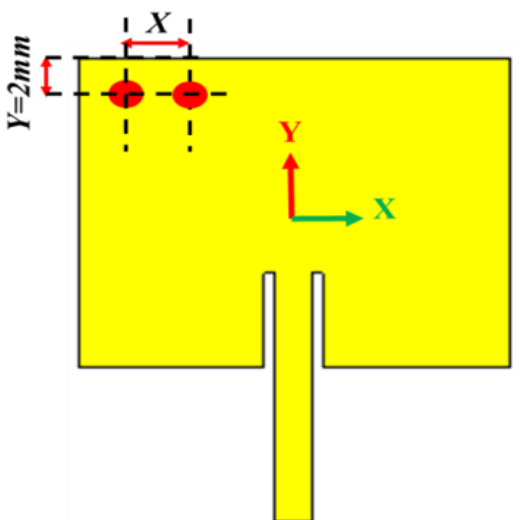

(a)

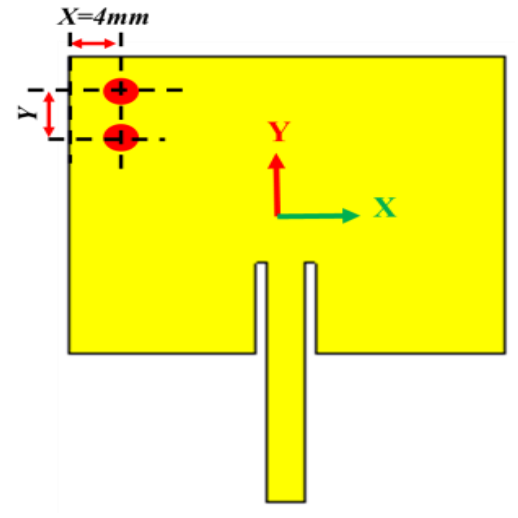

(b)

Figure 9: Two slots added in the patch (a) Horizontally at $Y=2 \mathrm{~mm}$ and different $X$-distances

(b) Vertically at $\mathrm{X}=\mathbf{4} \mathrm{mm}$ and different $\mathrm{Y}$-distances 




Figure 10: S- Parameter of two slots added in the patch horizontally at $Y=2 \mathbf{m m}$ and different $X$-distances

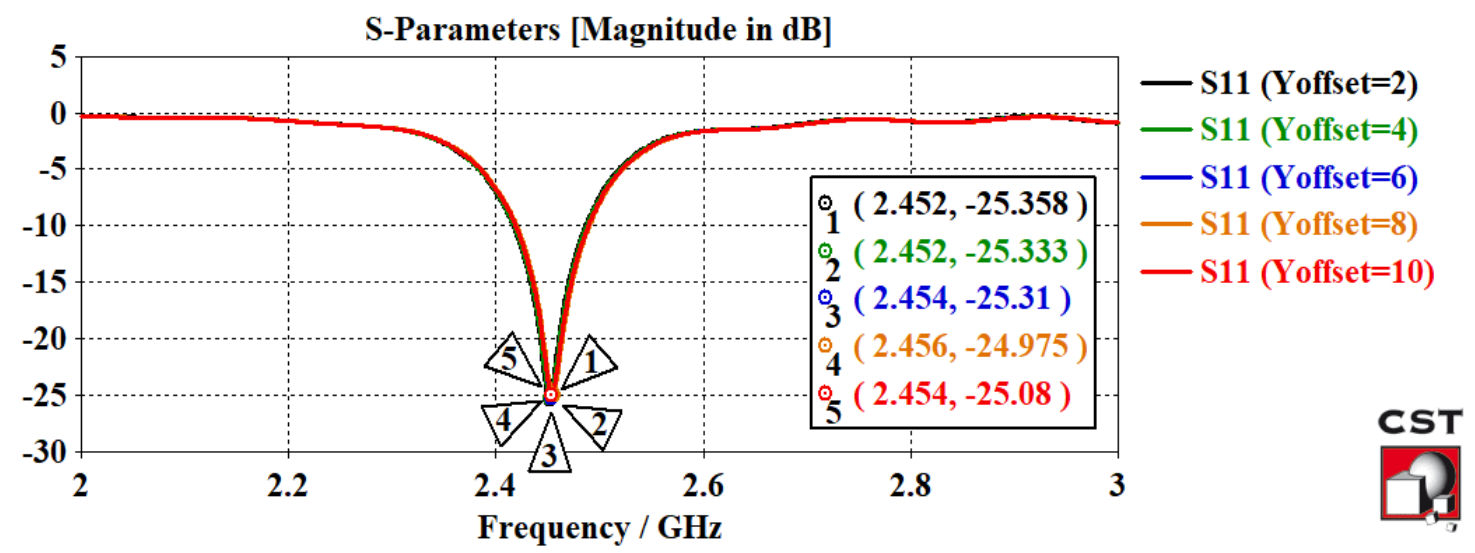

Figure 11: $S$ - Parameter of two slots added in the patch vertically at $X=4 \mathrm{~mm}$ and different $Y$-distances

Table 3: $S_{11}-$ Parameter of adding two slots in patch with different separation distances

\begin{tabular}{cccc}
\hline & $\begin{array}{c}\text { Separation } \\
\text { distances }\end{array}$ & $\boldsymbol{f} \mathbf{r}(\mathbf{G H z})$ & $\mathbf{S}_{\mathbf{1 1}}(\mathbf{d B})$ \\
\hline $\begin{array}{c}\text { Two slots added } \\
\text { horizontally at Y=2mm } \\
\text { and different X-axis (Fig }\end{array}$ & $\mathrm{X}=2$ & 2.45 & -25.324 \\
9-a) & $\mathrm{X}=4$ & 2.45 & -25.431 \\
& $\mathrm{X}=6$ & 2.45 & -25.385 \\
& $\mathrm{X}=8$ & 2.45 & -25.205 \\
& $\mathrm{X}=10$ & 2.45 & -25.199 \\
\hline & & & \\
Two slots added vertically & $\mathrm{Y}=2$ & 2.452 & -25.358 \\
at X=4mm and different & $\mathrm{Y}=4$ & 2.452 & -25.333 \\
Y-axis (Fig 9-b) & $\mathrm{Y}=6$ & 2.454 & -25.31 \\
& $\mathrm{Y}=8$ & 2.456 & -24.975 \\
& $\mathrm{Y}=10$ & 2.454 & -25.08 \\
\hline
\end{tabular}




\subsubsection{The Optimum Number Of Added Slots}

As mentioned later, the slots will be located horizontally at the top and bottom of the patch with a separation distance between them $(X=4 \mathrm{~mm}, Y=2 \mathrm{~mm})$, but the question is what is the number of slots? To answer this question several trials are processed. $S_{11}$ is evaluated for 2, 4, 8 and 12 slots and Table 4 summarizes the values of $S_{11}$ for different numbers of slots at the resonance frequency $2.45 \mathrm{GHz}$. It is observed that the best number of slots is eight since it provides less $S_{11}$ at $2.45 \mathrm{GHz}$. The final layout of proposed patch antenna with 8 slots is shown in Fig. 12.

Table 4: Different slots number trails



Figure 12: The final layout of optimized patch with 8- slots

\subsection{A Comparison between the Experimental Work and Simulation}

To examine the actual performance and validate the simulation results, the slotted RMPA prototype was fabricated at Banha Electronic Industries Company, Ministry of Military Production. Its performance in terms of S-parameter was measured with SMA connector by VNA vector network analyzer. A photograph of the manufactured slotted MSA with front and back view is depicted in Fig. 13 (a) and (b) respectively. Fig. 14 shows the return loss measurement of fabricated slotted MSA using network analyzer. The value of the return loss is $-25.01 \mathrm{~dB}$ at $2.449 \mathrm{GHz}$. In Fig. 15 a comparison of S-parameter between simulated and measured result is shown. The measured value of $S_{11}$ records $-25.01 \mathrm{~dB}$ at 2.449 $\mathrm{GHz}$ while the simulated value records $-25.424 \mathrm{~dB}$ at $2.45 \mathrm{GHz}$. Therefore, the measured results were consistent with the simulated results since both curves resonate at $2.45 \mathrm{GHz}$ and covered the desired band for ISM (2.4-2.483 GHz). 




(a)

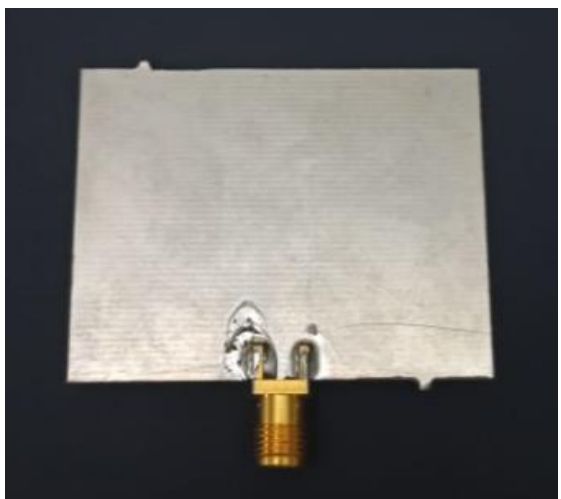

(b)

Figure 13: Fabricated model of the proposed slotted MSA (a) Front view (b) Back view

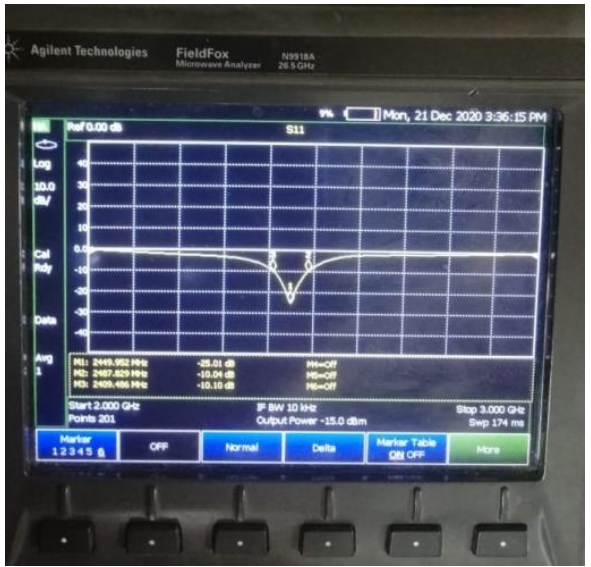

Figure 14: the return loss measurement of fabricated slotted MSA using network analyzer

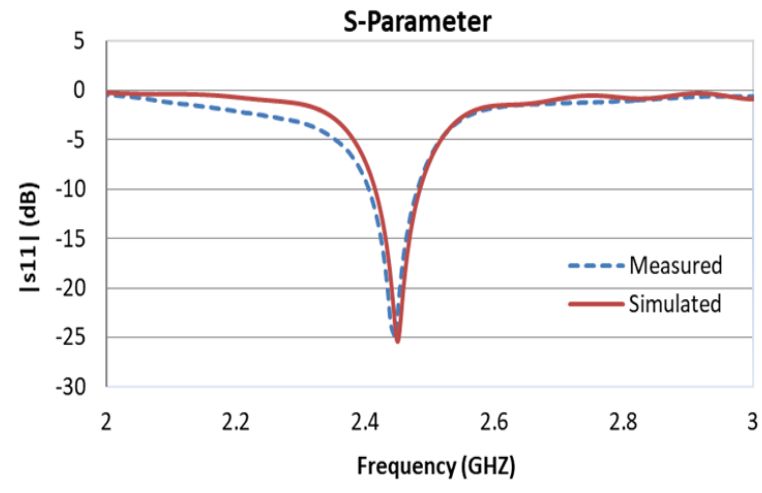

Figure 15: Measured and simulated S-Parameters curves of the proposed MSA with eight-slots

\subsection{Proposed Breast Model}

Female breast structure in this work is modeled as a basic breast structure which composed of of inhomogeneous tri-layers (skin, fat and gland), Each layer is characterized by its relative permittivity, conductivity and mass density. The electrical properties of materials used for model construction are computed according to a 4-Cole-Cole model described in (Gabriel, 1996). The numerical breast model is modeled as a cylinder with hemisphere of outer diameter $150 \mathrm{~mm}$. Two cross sections of the model are shown in Fig. 16. It is including a $5 \mathrm{~mm}$ thick skin layer, $15 \mathrm{~mm}$ thick fat, glandular tissue and a tumor with a spherical shape of radius $6 \mathrm{~mm}$. Breast is surrounded with water bolus layer of $1 \mathrm{~mm}$ thickness to improve coupling of the EM energy into tissues and cools the skin surface to minimize thermal hotspots as demonstrated by (Arunachalam et al., 2009; Li, 2013). Table 5 lists the electrical properties of materials used for model construction at $2.45 \mathrm{GHz}$ (Çalışkan et al., 2015; Xie et al., 2006).

Table 5: electrical properties of the numerical breast model

\begin{tabular}{cccccc}
\hline Tissue & Skin & Fat & Gland & Cancer & Water \\
\hline Relative Permittivity & 36 & 9 & 14 & 50 & 79 \\
Conductivity $\left(\mathbf{S} / \mathbf{m}^{\prime}\right)$ & 4 & 0.4 & 0.45 & 4 & 0.2 \\
Mass Density $\left(\mathbf{k g} / \mathbf{m}^{\mathbf{3}}\right)$ & 1100 & 900 & 1040 & 1040 & 994 \\
\hline
\end{tabular}




\section{MODELLING AND SIMUALUATION OF PROPOSED DESIGN}

The commercially available electromagnetic simulator CST studio 2019 was used to model and simulate the hyperthermia treatment system. It provides a user-friendly computer aided design (CAD) environment to generate the different geometries based on FEM. FEM is the time domain solution of Maxwell equation and uses a piecewise approximation to solve the governing Pennes bioheat transfer equation

(BHTE). The computational domain was discretized into a tetrahedral volumetric cell that forms the mesh. The time domain solver is used to simulate and calculate the EM field and SAR distribution inside the computational domain.

\subsection{Antenna Array Configuration}



(a)

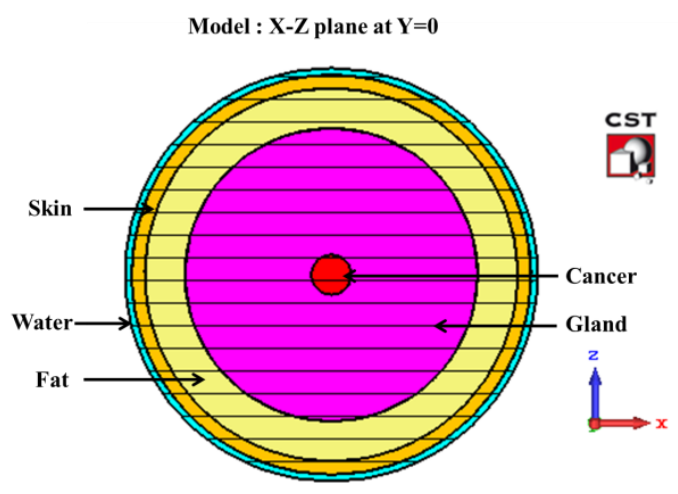

(b)

Figure 16: Cross sections of a 3-D breast model at (a) $Z=0 \mathrm{~mm}$ and (b) $Y=0 \mathrm{~mm}$.

The hyperthermia system in this work composed of eight MSA instead of single element to increase energy deposition and ability to focus energy at different location with the breast as will be discussed in section 3.3.2. These elements will be arranged around the breast with water layer in a circular

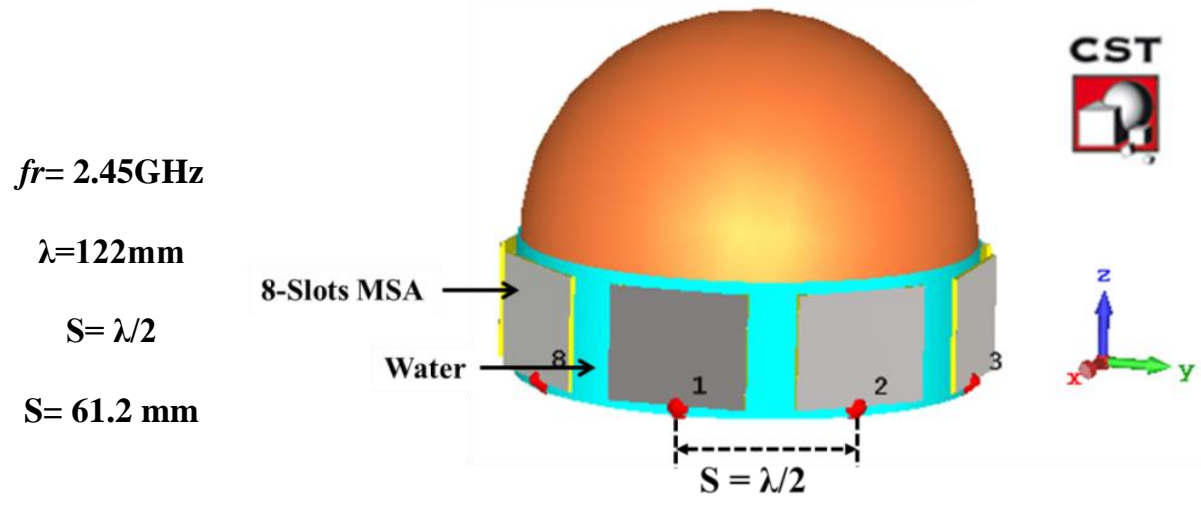

Figure 17: The proposed breast model surrounding by eight MSAs with eight slots and water matching layer

configuration with minimum interspacing distance $S$ of $\lambda / 2 \mathrm{~mm}$ as shown in Fig. 17 . 


\subsection{Specific Absorption Rate Distribution (SAR)}

The temperature rise during the hyperthermia is related to the EM energy absorption by human tissue. This power absorption is characterized by the specific absorption rate (SAR) which clarified by (Michalowska et al., 2012; Subramanian et al., 2018) and calculated as shown in (1). Then power dissipated in the tissue per unit volume $\left(Q_{\text {ext }}\right)$ produced by the external EM radiation is calculated as shown in (2). While the thermal calculation is followed to estimate the temperature, profile produced by $\left(Q_{\text {ext }}\right)$ as mentioned by (Thanh Nguyen, 2015) by applying the well-known Pennes BHTE (3) in terms of thermal properties of the breast phantom which shown in Table 6.

$$
\begin{aligned}
& \mathrm{SAR}=\frac{\sigma \mid \text { Erms }\left.\right|^{2}}{\rho}=\frac{\sigma \mid \text { Emax }\left.\right|^{2}}{2 \rho}(\mathrm{W} / \mathrm{Kg}) \\
& \mathrm{Q}_{\text {ext }}=\rho(\mathrm{SAR})=\frac{\sigma \mid \text { Emax }\left.\right|^{2}}{2}\left(\mathrm{~W} / \mathrm{m}^{3}\right) \\
& \rho_{\mathrm{t}} \mathrm{c}_{\mathrm{t}}\left(\frac{\partial \mathrm{T}_{\mathrm{t}}}{\partial \mathrm{t}}\right)=\nabla \cdot\left(\mathrm{K}_{\mathrm{t}} \nabla \mathrm{T}_{\mathrm{t}}\right)+\mathrm{B}\left(\mathrm{T}_{\mathrm{a}}-\mathrm{T}_{\mathrm{t}}\right)+\mathrm{Q}_{\text {met }}+\mathrm{Q}_{\text {ext }}
\end{aligned}
$$

Where $\rho_{\mathrm{t}}(\mathrm{kg} / \mathrm{m} 3)$ is the tissue density, $\mathrm{c}_{\mathrm{t}}\left(\mathrm{KJ} / \mathrm{Kg}^{\circ} \mathrm{K}\right)$ is the tissue specific heat, $\mathrm{Kt}\left(\mathrm{W} / \mathrm{m}^{\circ} \mathrm{K}\right)$ is the tissue thermal conductivity, $\mathrm{Q}_{\mathrm{met}}(\mathrm{W} / \mathrm{m} 3)$ is the metabolic heat generation which is usually very small compared to the external power deposition $\mathrm{Q}_{\text {ext }}, \mathrm{T}_{\mathrm{t}}\left({ }^{\circ} \mathrm{K}\right)$ is the local tissue temperature, $\mathrm{Ta}\left({ }^{\circ} \mathrm{K}\right)$ is the arterial temperature, $\mathrm{B}\left(\mathrm{W} / \mathrm{m}^{3 \circ} \mathrm{K}\right)$ blood perfusion coefficient.

Table 6: Thermal properties of proposed breast model

\begin{tabular}{ccccc}
\hline Tissue & $\begin{array}{c}\text { Thermal conductivity } \\
\mathbf{K}\left(\mathbf{W} / \mathbf{m}^{\circ} \mathbf{K}\right)\end{array}$ & $\begin{array}{c}\text { Specific Heat } \\
\mathbf{C}\left(\mathbf{K J} / \mathbf{K g}^{\circ} \mathbf{K}\right)\end{array}$ & $\begin{array}{c}\text { Blood flow } \\
\text { coffecient } \\
\mathbf{B}\left(\mathbf{W} / \mathbf{m}^{3} \mathbf{K}\right)\end{array}$ & $\begin{array}{c}\text { Metabolic heat } \\
\text { generation rate } \\
\mathbf{Q m}(\mathbf{W} / \mathbf{m} \mathbf{3})\end{array}$ \\
\hline Skin & 0.2930 & 3.500 & 9100 & 1620 \\
Fat & 0.2010 & 2.500 & 2000 & 300 \\
Gland & 0.6240 & 3.600 & 400000 & 60000 \\
Tumor & 0.6240 & 3.700 & 400000 & 60000 \\
Water & 0.6 & 4.186 & NA & NA \\
\hline
\end{tabular}

Each MSA is feeding by a discrete port type, modeled by a lumped element, consisting of a current source with inner impedance placed in parallel that excites and absorbs power. The internal resistance Ri equal $54.79 \mathrm{ohm}$ to match with obtained characteristic impedance of antenna. This discrete port type realizes a stimulated power of $\operatorname{Ii}(\mathrm{t}) 2 * \mathrm{Ri}=1 \mathrm{Watt}$.

Four values of the current amplitudes are used during the simulation. These values are 135, 190, 235, and $270 \mathrm{~mA}$ that is corresponding to a simulated input power $\mathrm{Pi}=1,2,3$, and 4 watt (Ii(t) $2 * \mathrm{Ri}$ ) respectively, and all phases were assigned by zero degree. The maximum electric field and SAR values were simulated for a $12 \mathrm{~mm}$ tumor diameter located at the center of the breast model $(X=0, Y=0, Z=0)$ for the proposed MSAs with and without eight slots.

The results are summarized in Table 7. It observed that MSA with eight slots record a higher electric field and SAR values at the tumor compared to the MSA without slots for all values of input power. Therefore, the MSA with eight slots is used to simulate and calculate temperature profile inside the model as will be discussed in section 3.3. 
Table 7: Max E-filed and SAR values for a tumor located at the center of the breast model

\begin{tabular}{ccccc}
\hline & \multicolumn{2}{c}{ MSA } & \multicolumn{2}{c}{ MSA } \\
& Without slot & With eight slots \\
\hline Input power $\boldsymbol{P}_{\boldsymbol{i}}$ (Watt) & $\begin{array}{c}\text { Max E-field } \\
(\mathbf{V} / \mathbf{m})\end{array}$ & $\begin{array}{c}\text { SAR } \\
(\mathbf{W} / \mathbf{k g})\end{array}$ & $\begin{array}{c}\text { Max E-field } \\
(\mathbf{V} / \mathbf{m})\end{array}$ & $\begin{array}{c}\text { SAR } \\
(\mathbf{W} / \mathbf{k g})\end{array}$ \\
\hline 1 & 83.05 & 0.920 & 84.58 & 0.957 \\
2 & 117.5 & 1.842 & 119.6 & 1.916 \\
3 & 143.9 & 2.763 & 146.5 & 2.873 \\
4 & 166.1 & 3.685 & 169.2 & 3.831 \\
\hline
\end{tabular}

Fig. 18 demonstrates SAR distribution patterns in transverse phantom cutting for MSAs with slots for all input power values. The highest SAR (red color) is concentrated in the middle of the breast where the tumor is located. High level of SAR occurs (not shown on the figure) at the near field neighboring with each patch.

The problem of high SAR values at the skin layer can therefore be regulated by the use of a water bolus that serves as a good heat exchanger to prevent overheating of the skin and boost the connecting medium between the antenna and the skin (DG et al., 2002).
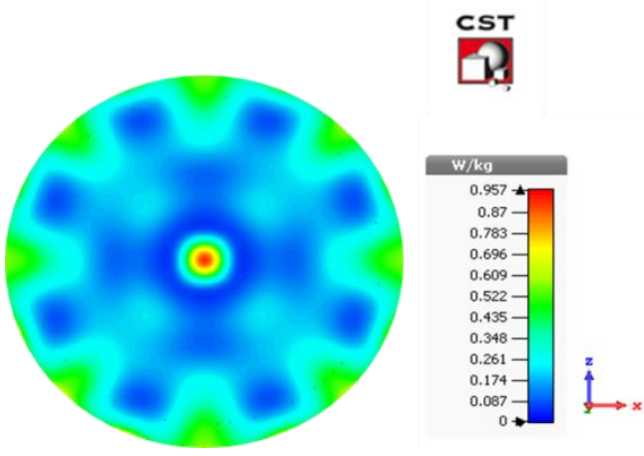

(a)

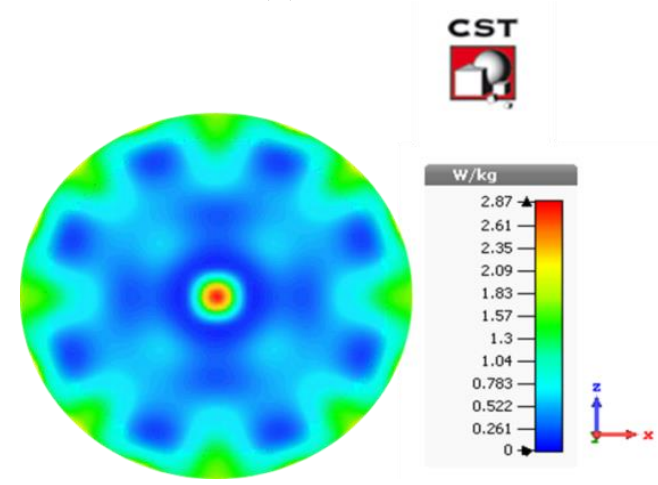

(c)

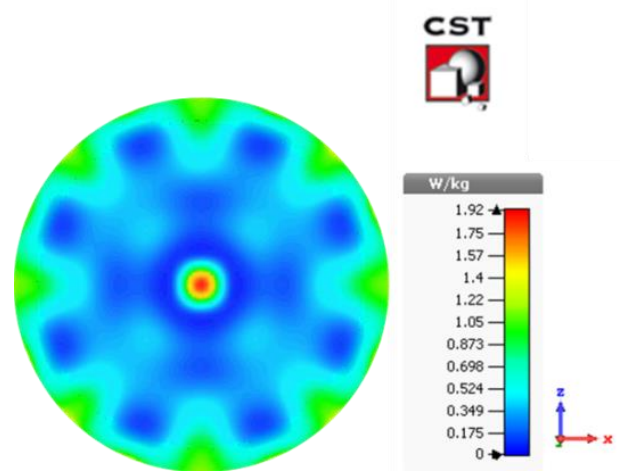

(b)



(d)

Figure 18: Maximum SAR distribution for each input feeding power (a) 1 Watt, (b) 2 Watt, (c) 3 Watt and (d) 4 Watt

\subsection{Thermal simulation}

In this section, the effect of the different input values of power amplitudes and phases for the 8- slots MSAs elements around the breast to reach the desired hyperthermia temperature at the tumor will be discussed. 


\subsubsection{Effect of MSA feeding power}

The goal here is to achieve the required feeding power amplitude to achieve the desired hyperthermia temperature at the center of the proposed breast model. Each MSA is feed with input power amplitude $\left(P_{i}\right)$ and the corresponding maximum temperature is achieved as shown in Table 8. Fig. 19 shows the temperature distribution for the eight MSAs with eight slots according to different values of $P_{i}$. It noted that the maximum temperature required for hyperthermia can be reached_up to $44.29{ }^{\circ} \mathrm{C}$ within the tumor at input power 4 watt for each MSA. However, it notices that surrounding healthy tissues also affected with hyperthermia temperature (above $42^{\circ} \mathrm{C}$ ) as shown in Fig. 21.

To minimizing the overheating, each MSA have been moved away from the breast model with $2 \mathrm{~mm}$ then moved it down in the negative direction of Y-axis with a distance of $5 \mathrm{~mm}$ as shown in Fig. 20. As a result, the focal spot was reduced and the maximum temperature $\left(43^{\circ} \mathrm{C}\right)$ was concentrated within $12 \mathrm{~mm}$ diameter tumor without effect the healthy tissue as shown in Fig. 22.

It can also be noticed that the required temperature in the tumor volume after editing the position of antenna was achieved at low level of input power equal $1 \mathrm{~W}$ att for each antenna instead of $\quad P i=4$ Watt. Also if the input power is increased above 1 Watt for each antenna, the healthy tissue will be affected with higher temperature.

Table 8: Maximum temperature corresponding to input feeding power

\begin{tabular}{ccccc}
\hline $\begin{array}{c}\boldsymbol{P i} \text { (Watt) for eight MSAs } \\
\text { with eight slots }\end{array}$ & $\mathbf{1}$ & $\mathbf{2}$ & $\mathbf{3}$ & $\mathbf{4}$ \\
\hline $\begin{array}{c}\text { Maximum Temperature } \\
\left({ }^{\mathbf{0}} \mathbf{C}\right)\end{array}$ & 38.81 & 40.63 & 42.44 & 44.26 \\
\hline
\end{tabular}

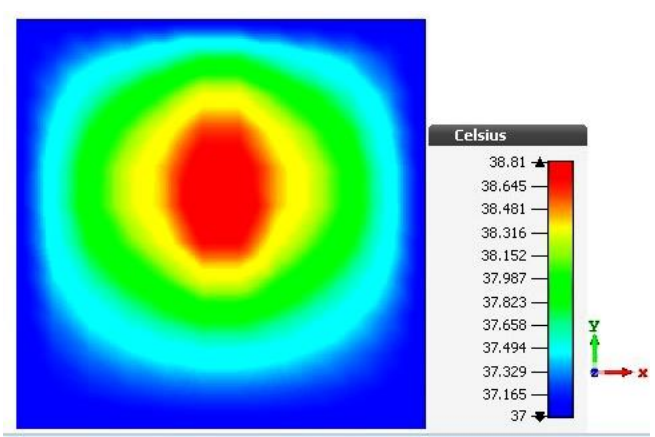

(a)

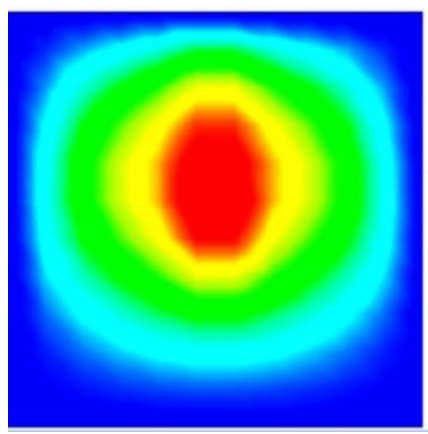

(c)

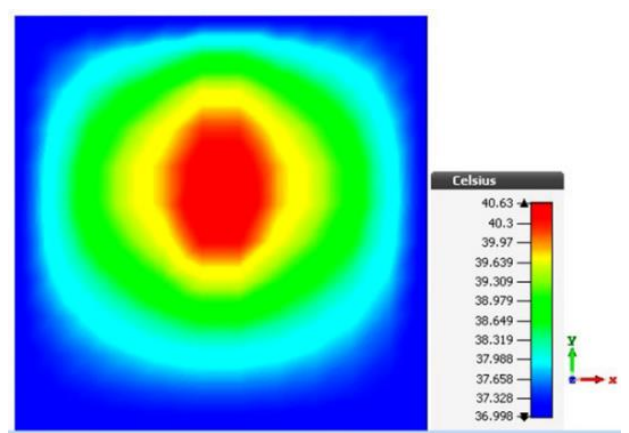

(b)



(d)

Figure 19: Maximum temperature distribution for each input feeding power (a) 1 Watt, (b) 2 Watt, (c) 3 Watt and (d) 4 Watt 


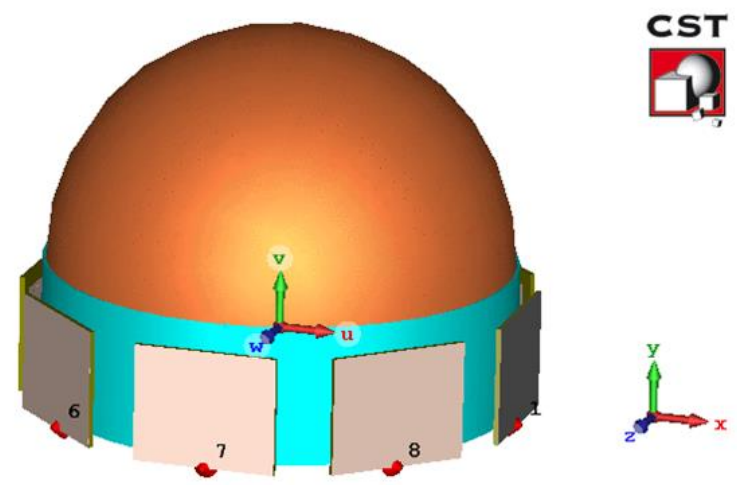

Figure 20: The proposed breast model surrounding by eight MSAs with eight slots after editing antenna positions

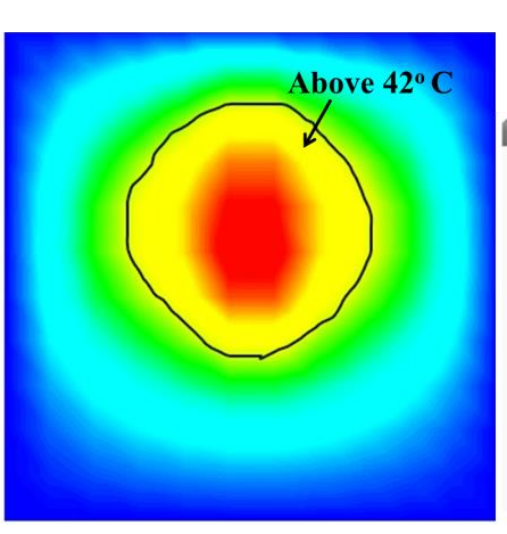

(a)

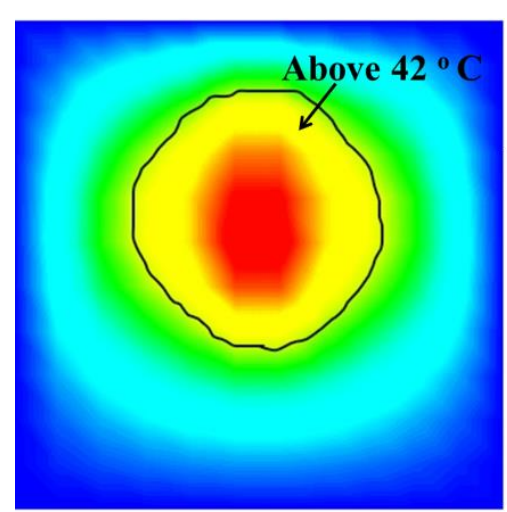

(b)
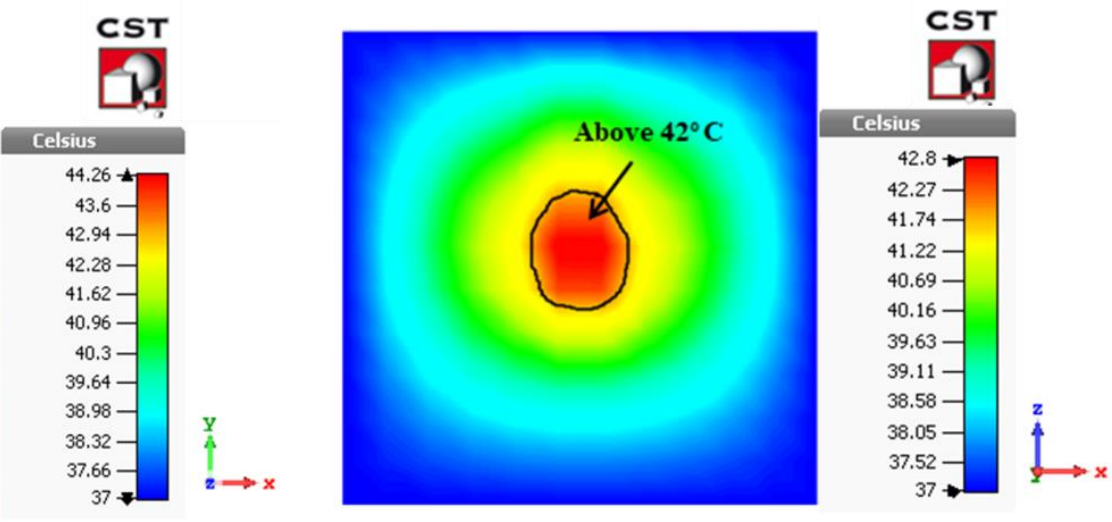

(a)
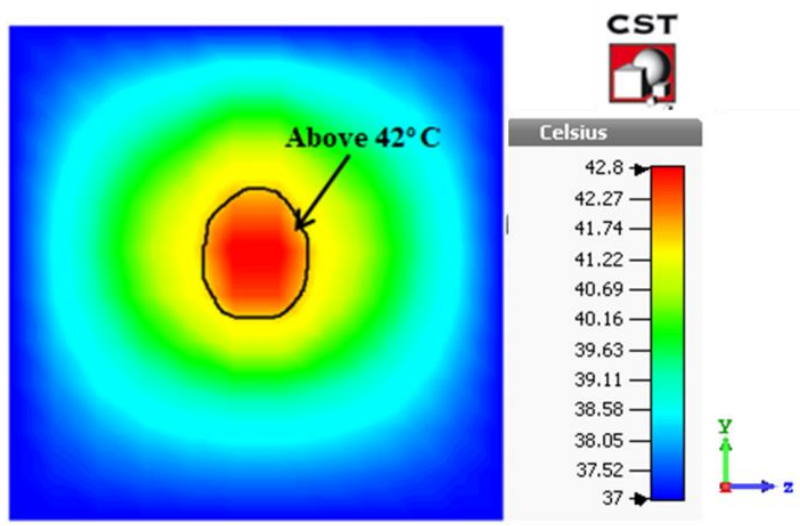

(b) 


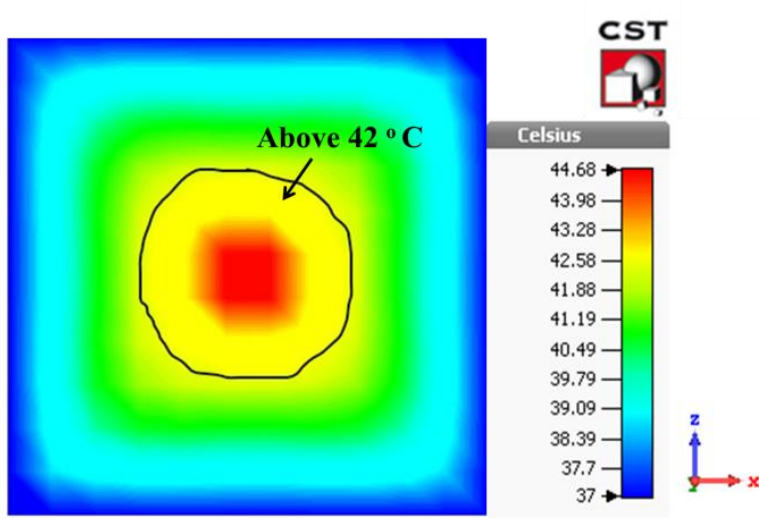

(c)

Figure 21: Temperature distribution in three planes (a) $\mathrm{XY}$, (b) $\mathrm{YZ}$ and (c) $\mathrm{XZ}$ respectively at $\mathrm{d}=0 \mathrm{~mm}$ and $P i=4$ Watt

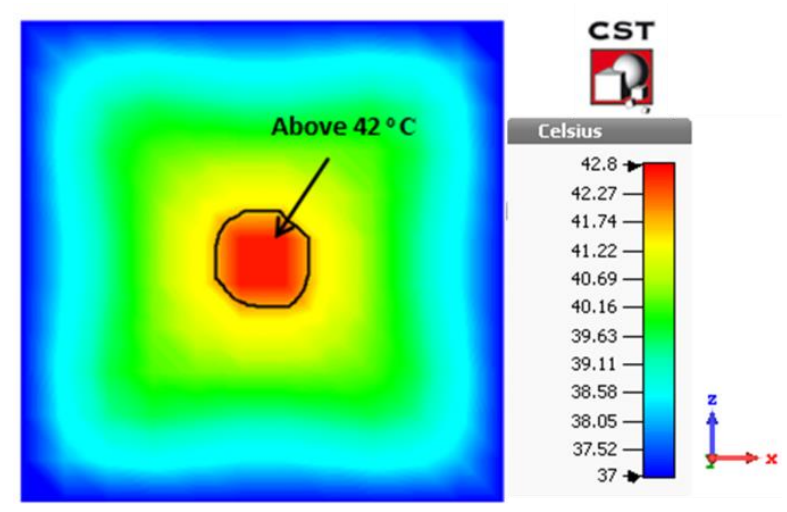

(c)

Figure 22: Temperature distribution in three planes (a) $\mathrm{XY}$, (b) $\mathrm{YZ}$ and (c) $\mathrm{XZ}$ respectively at $\mathrm{d}=\mathbf{2} \mathrm{mm}$ and $P i=1$ Watt

\subsubsection{Effect of changing phases and feeding current distribution of MSAs for beam steering}

This section explains how to steer the heating to a specific area of the breast. In order to illustrate the effect of phases $\left(\Phi_{i}^{\circ}\right)$ and feeding current $\left(I_{i}\right)$ distribution on steering the heat area, the proposed breast model is divided into four quarters $(\mathrm{Q} 1, \mathrm{Q} 2, \mathrm{Q} 3$ and $\mathrm{Q} 4)$. The eight ports of MSA from port 1 to port 8 are arranged around the breast as shown in Fig.23. The central ports of each quarter are (port2, port4, and port6, port 8). The focusing method presented in (Heba Abdelhamid Elkayal et al., 2015) was dependent on changing the phases of the antenna array elements. In this work the focusing method is not depended only on the phases of MSAs elements, but it also depends on how the current is distributed for the array elements. Several trials given in Table 9 and Fig. $\mathbf{2 3}$ are processed to decide the optimum feeding current and phase's values of each element of MSA array to steer the heat area into a certain quarter of the breast.



Figure23: The arrangement of each MSA element around the breast model

Trial (0): feeding current $\left(I_{i}\right)=135 \mathrm{~mA}$ and phases $\left(\Phi_{i}{ }^{\circ}\right)=$ zero for all elements, as a result heated area was at the center of the breast as shown in Fig. 24 (a).

Trial (1): values of $\left(I_{i}\right)$ and $\left(\Phi_{i}{ }^{\circ}\right)$ for focusing heat into Q1, the temperature distribution shown at Fig. 24 (b).

Trial (2): values of $\left(I_{i}\right)$ and $\left(\Phi_{i}{ }^{\circ}\right)$ for focusing heat into Q2, the temperature distribution shown at Fig. 24 (c) 
Trial (3): values of $\left(I_{i}\right)$ and $\left(\Phi_{i}{ }^{\circ}\right)$ for focusing heat into Q3, the temperature distribution shown at Fig. 24 (d)

Trial (4): values of $\left(I_{i}\right)$ and $\left(\Phi_{i}{ }^{\circ}\right)$ for focusing heat into Q4, the temperature distribution shown at Fig. 24 (e)

From the previous trials, a general rule to steer the beam to achieve hyperthermia in any quarter of the breast should follow:

1- A high feeding current with a value of $I i=190 \mathrm{~mA}$ should be assigned to the three MSAs surrounding the breast quarter, while the remaining elements should be assigned with lower input current $I i=135 \mathrm{~mA}$.

2- The phase value of the three MSAs surrounding the breast quarter $\left(\Phi_{i}{ }^{\circ}\right)$ should have values of $(0$, $100^{\circ}$, and $-50^{\circ}$ ) respectively, while the phase of the MSA element next to the element having a phase $=-50^{\circ}$ should be $60^{\circ}$. A progressive phase of $10^{\circ}$ is used to the rest of elements.

Table 9: Current amplitude $\left(I_{i}\right)$ distributions and phases $\left(\Phi_{i}{ }^{\circ}\right)$ trails

\begin{tabular}{|c|c|c|c|c|c|c|c|c|c|}
\hline $\begin{array}{c}\text { Iterations } \\
\text { No. } \\
\end{array}$ & Current & Port 1 & Port 2 & Port 3 & Port 4 & Port 5 & Port 6 & Port 7 & Port 8 \\
\hline \multirow{2}{*}{$\begin{array}{c}0 \\
\text { focusing at } \\
\text { breast } \\
\text { center }\end{array}$} & & 135 & 135 & 135 & 135 & 135 & 135 & 135 & 135 \\
\hline & $\boldsymbol{\Phi}_{i}^{\circ}$ & 0 & 0 & 0 & 0 & 0 & 0 & 0 & 0 \\
\hline \multirow{2}{*}{$\begin{array}{c}1 \\
\text { focusing on } \\
\text { Q1 }\end{array}$} & $I_{i}(\mathbf{m A})$ & 190 & 190 & 190 & 135 & 135 & 135 & 135 & 135 \\
\hline & $\Phi_{i}^{\circ}$ & 0 & -100 & -50 & 60 & 70 & 80 & 90 & 100 \\
\hline \multirow{2}{*}{$\begin{array}{c}2 \\
\text { focusing on } \\
\text { Q2 }\end{array}$} & $I_{i}(\mathbf{m A})$ & 135 & 135 & 190 & 190 & 190 & 135 & 190 & 135 \\
\hline & $\boldsymbol{\Phi}_{i}^{\circ}$ & 90 & 100 & 0 & -100 & -50 & 60 & 70 & 80 \\
\hline \multirow{2}{*}{$\begin{array}{c}3 \\
\text { focusing on } \\
\text { Q3 }\end{array}$} & & 135 & 135 & 135 & 135 & 190 & 190 & 190 & 135 \\
\hline & $\boldsymbol{\Phi}_{i}^{\circ}$ & 70 & 80 & 90 & 100 & 0 & -100 & -50 & 60 \\
\hline \multirow{2}{*}{$\begin{array}{c}4 \\
\text { focusing on } \\
\text { Q4 }\end{array}$} & $I_{i}(\mathbf{m A})$ & 190 & 135 & 135 & 135 & 135 & 135 & 190 & 190 \\
\hline & $\boldsymbol{\Phi}_{i}^{\circ}$ & -50 & 60 & 70 & 80 & 90 & 100 & 0 & -100 \\
\hline
\end{tabular}

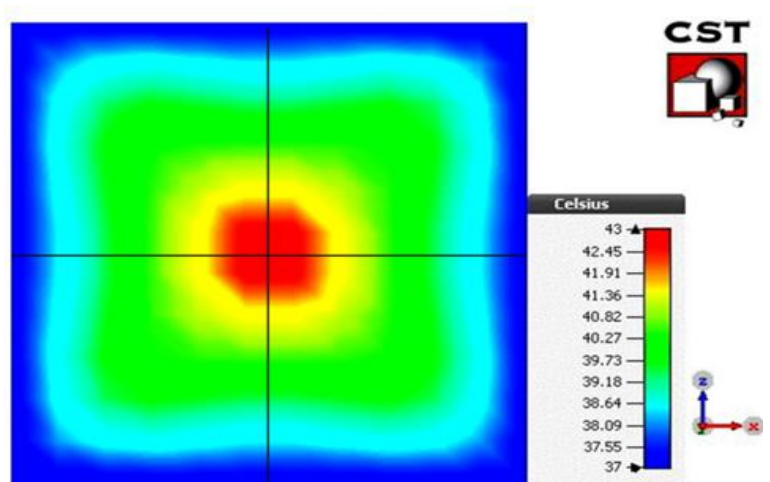

(a) 


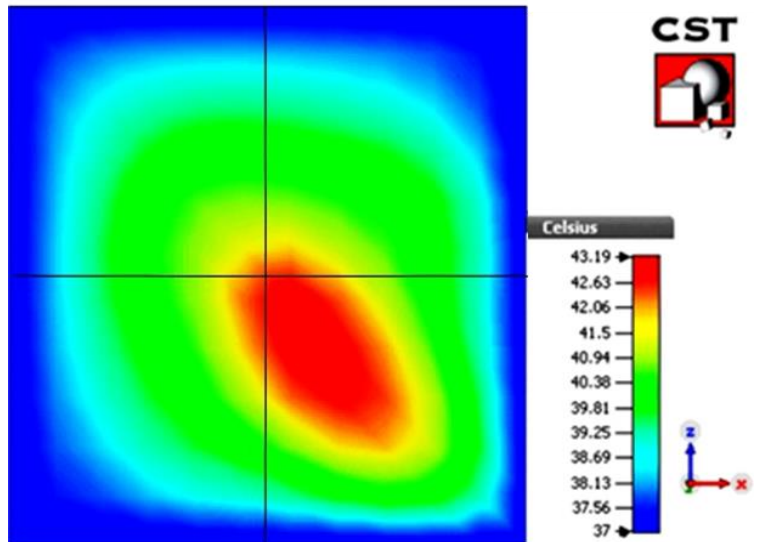

(b)



(d)
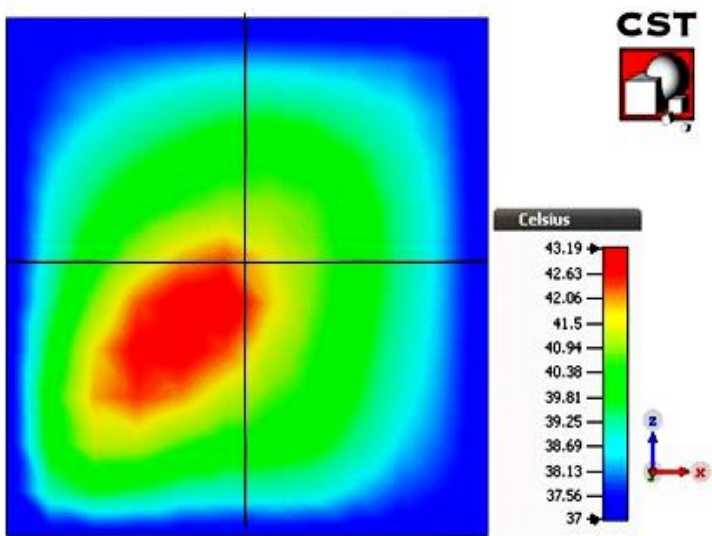

(c)

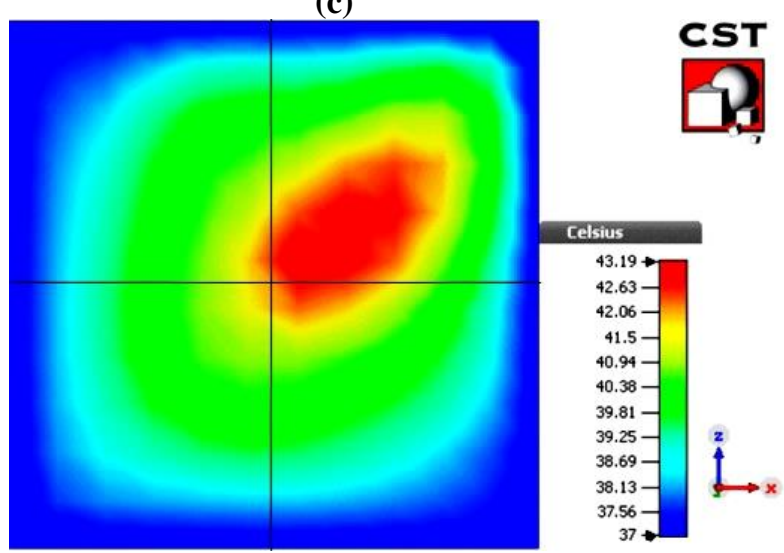

(e)

Figure 24: Temperature distribution at different locations of the breast (a)Center, (b) Q1 ,(c)Q2, (d)Q3 and (d)

\section{CONCLUSION}

Q4

The objective of hyperthermia treatment for cancer is to raise the temperature at the tumor volume above $42^{\circ} \mathrm{C}$ for a sufficient period of time while preserving normal physiological temperatures (well below $42^{\circ} \mathrm{C}$ ) in the surrounding tissue. This paper presented a design of a slotted microstrip patch antenna array (eight elements) operating at $2.45 \mathrm{GHz}$ employed for breast cancer hyperthermia treatment. The antenna array structure and the 3D proposed breast model are simulated using CST studio. High-performance finite element software is used for designing, analyzing and modeling. Each MSA was modified by introducing eight-slots with radius $0.5 \mathrm{~mm}$ in the patch resulting in an increase of the SAR and E-field values at the target. The results show:

- Hyperthermia (temperature over $42^{\circ} \mathrm{C}$ ) is reached at the tumor volume without involving the surrounding tissue at input feeding power equal 1 watt for each element.

- Also, the effect of feeding current distributions and phases of the eight MSAs on steering the antenna array beam to a certain area of the breast is presented.

- Furthermore, heating spot is focused at the center of the breast if all elements assigned with the same current amplitude $135 \mathrm{~mA}$ and with zero phase values.

- Finally, to focus the heat in any quarter of the breast, the input current should be distributed unevenly for all elements with different phases. Where the three elements that surrounding the quarter needed to be heated should be assigned with higher input current $190 \mathrm{~mA}$ and phases values as $\left(0,-100^{\circ},-50^{\circ}\right)$. 
While the remaining elements should be assigned with lower input current $135 \mathrm{~mA}$ and the phase of the MSA element next to the element having a phase $=-50^{\circ}$ should be $60^{\circ}$. Also, a progressive phase of $10^{\circ}$ for the rest of elements is used.

\section{FUTURE WORK}

* In future an exact heterogeneous 3D model of the breast anatomy will be constructed from MRI images and apply the proposed MSA array to prove its efficiency for hyperthermia treatment.

* The proposed hyperthermia system can be tested on various types of tumor.

* The heating can be delivered into cancerous tissue using magnetized nanoparticles such as iron, where iron immersed in the cancerous tissue and the heating is done by magnetizing of nanoparticles from the outside through the EM field.

\section{REFERENCES}

[1] Arunachalam, K., MacCarini, P. F., Schlorff, J. L., Birkelund, Y., Jacobsen, S., \& Stauffer, P. R. (2009). Design of a water coupling bolus with improved flow distribution for multi-element superficial hyperthermia applicators. International Journal of Hyperthermia, 25(7), 554-565. https://doi.org/10.3109/02656730903124506

[2] Balanis, C. A. (2016). Antenna theory: analysis and design (4th ed.). John Wiley \& Sons.

[3] Bengal, W. (2014). Effect of Dielectric Permittivity and Height on a Microstrip-Fed Rectangular Patch Antenna. International Journal of Electronics and Communication Technology (IJECT), 5(2), 129130.

[4] Bernard, V., Paul, J., \& Iloh, I. (2013). Microstrip antenna design using transmission line model. International Journal of Emerging Technology and Advanced Engineering, 3(11), 410-415.

[5] Çalışkan, R., Gültekin, S. S., Uzer, D., \& Dündar, Ö. (2015). A microstrip patches antenna design for breast cancer detection. Procedia-Social and Behavioral Sciences, 195, 2905-2911.

[6] Chaudhary, S. S., Mishra, R. K., Swarup, A., \& Thomas, J. M. (1984). Dielectric properties of normal $\&$ malignant human breast tissues at radiowave \& microwave frequencies. Indian Journal of Biochemistry \& Biophysics, 21(1), 76-79.

[7] DG, N., PR, S., S, J., \& F, R. (2002). SAR pattern perturbations from resonance effects in water bolus layers used with superficial microwave hyperthermia applicators. International Journal of Hyperthermia, 18(3), 180-193. https://doi.org/10.1080/0265673011011919

[8] Gabriel, C. (1996). Compilation of the dielectric properties of body tissues at RF and microwave frequencies. King's Coll London (United Kingdom).

[9] Heba Abdelhamid Elkayal, Nour Eldin Ismail, \& Mona Lotfy. (2015). Microwaves for breast cancer treatments. In Alexandria Engineering Journal (Vol. 54, Issue 4, pp. 1105-1113).

[10] Kara, M. (1996). Microstrip antennae with various substrate thicknesses. The University of Adelaide.

[11] Korkmaz, E., Isık, O., \& Sagkol, H. (2015). A directive antenna array applicator for focused electromagnetic hyperthermia treatment of breast cancer. 2015 9th European Conference on Antennas and Propagation (EuCAP), 1-4.

[12] Kumar, G., \& Ray, K. P. (2002). Broadband microstrip antennas. Artech House Antennas and Propagation Library. www.artechhouse.com

[13] Kumar, R., Shinde, J. P., \& Uplane, M. D. (2009). Effect of slots in ground plane and patch on microstrip antenna performance. International Journal of Recent Trends in Engineering, 2(6), 34-36. 
[14] Leggio, L., Varona, O. de, \& Dadrasnia, E. (2015). A Comparison between Different Schemes of Microwave Cancer Hyperthermia Treatment by Means of Left-Handed Metamaterial Lenses. Progress In Electromagnetics Research, 150, 73-87. https://doi.org/10.2528/PIER14101408

[15] Li, X. (2013). Body matched antennas for microwave medical applications. Karlsruher Institut für Technologie (KIT) Scientific Publishing. www.ksp.kit.edu

[16] Matin, M. A., \& I.Sayeed, A. (2010). A design rule for inset-fed rectangular microstrip patch antenna. WSEAS Transactions on Communications, 9(1), 63-72.

[17] McNeil, P. (n.d.). What are the ISM Bands, and What Are They Used For? https://blog.pasternack.com/uncategorized/what-are-the-ism-bands-and-what-are-they-used-for/

[18] Michalowska, J., Miaskowski, A., \& Wac-Włodarczyk, A. (2012). Numerical analysis of high frequency electromagnetic field distribution and specific absorption rate in realistic breast models. Przegląd Elektrotechniczny, 88(12b), 97-99.

[19] Ndujiuba, C. U., Ilesanmi, O. A., \& Agboje, O. E. (2017). Bandwidth Enhancement of An Inset-Fed Rectangular Patch Antenna using Partial Ground with Edge-cut Method. International Journal of Electromagnetics and Applications, 7(1), 9-16. https://doi.org/10.5923/j.ijea.20170701.02

[20] Nikolova, N. K. (2011). Microwave imaging for breast cancer. IEEE Microwave Magazine, 12(7), 78-94. https://doi.org/10.1109/MMM.2011.942702

[21] Patel, S. K. (2015). Improvement of efficiency parameter of a microstrip patchor WLAN antenna operating at $2.4 \mathrm{GHz}$ for WLAN. IOSR Journal of Electronics and Communication Engineering (IOSRJECE), 10(6), 1-6.

[22] Paul, L. C., Hosain, M. S., Sarker, S., Prio, M. H., \& Monir Morshed, A. K. S. (2015). The effect of changing substrate material and thickness on the performance of inset feed microstrip patch antenna. American Journal of Networks and Communications, 4(3), 54-58.

[23] Paul, L. C., Pramanik, R. K., Rashid, M. U., Hossain, N., Mahmud, Z., \& Islam, M. T. (2019). Wideband inset fed slotted patch microstrip antenna for ISM band applications. 2019 Joint 8th International Conference on Informatics, Electronics \& Vision (ICIEV) and 2019 3rd International Conference on Imaging, Vision \& Pattern Recognition (IcIVPR), 79-84.

[24] Society, A. C. (2020). Cancer facts \& figures 2020. American Cancer Society Journal, CA: A Cancer Journal for Clinicians, 1-70.

[25] Subramanian, S., Sundarambal, B., \& Nirmal, D. (2018). Investigation on simulation-based specific absorption rate in ultra-wideband antenna for breast cancer detection. IEEE Sensors Journal, 18(24), 10002-10009. https://doi.org/10.1109/JSEN.2018.2875621

[26] Tayel, M. B., Badwai, M. I., \& Hasan, H. T. A. (2016). A novel microwave image slices technique for early breast tumors detection based on metalenses. The 7th International Conference on Metamaterials, Photonic Crystals and Plasmonics, 1158-1167.

[27] Thanh Nguyen, P. (2015). Focusing microwave hyperthermia in realistic environment for breast cancer treatment. The University of Queensland,Ausralia.

[28] Waterhouse, R. (2003). Microstrip Patch Antennas: A Designer's Guide: A Designer's Guide. Springer Science \& Business Media.

[29] Xie, Y., Guo, B., Xu, L., Li, J., \& Stoica, P. (2006). Multistatic adaptive microwave imaging for early breast cancer detection. IEEE Transactions on Biomedical Engineering, 53(8), 1647-1657. https://doi.org/10.1109/TBME.2006.878058 